\title{
DISTRIBUTION OF INVASIVE PLANT Ulex europeus IN HORTON PLAINS NATIONAL PARK
}

\author{
M C Devendra', H S Amarasekera' AND S Wahala ${ }^{2}$ \\ 'Department of Forestry and Environment Science, \\ University of Sri Jayewardenepura, Nugegoda. \\ 'Young Biologists' Association
}

One of the most sensitive problems facing the conservation and management of Horton Plains National Park is the spreading of Uler europeus (gorse), an invasive plant species. To effectively manage and control this species it is necessary to have a sound knowledge of its distribution within this park.

This study was carried out to find the extent and distribution of Ulex europerus in the park and finally to prepare a map showing the extent and distribution. The percent coverage was assessed using $2 \mathrm{~m} \times 2 \mathrm{~m}$ quadrats. In each quadrat percentage cover of reproductives and non-reproductives were measured.

According to the results of this study, about tha of the area is covered by Ulex europeus. Total amount of the area which covers more than $80 \%$ of Ulex europeus is 2.4 ha. The area which consists of less than $80 \%$ of Ulex europeus is 3.31 ha. The extent of reproductives and non reproductives are also presented in the paper. Findings on the distribution pattern of the species show that the area around the main gate and Farr Inn guest house is the most densely and continuously distributed area with more than $80 \%$ coverage of Ulex curopeus. Except this there are a few isolated patches on either side of the road and trail with more than $80 \%$ coverage of Ulex europeus. The distribution of the Ulex europeus plants are mainly restricted along the stream from Black bridge to Gempit pool. The density of the species gradually decreased from up stream to down stream but it was higher in the areas where witter is stagnatted along the stream. It is interesting to note that there are no plants of Ulex curopeus found inside the natural forest except at the margins of the forest. 